\title{
Sharing tacit business knowledge between founder and successor in family business: case studies in Vietnam
}

\author{
Thanh Trung Pham, \\ University of Gloucestershire Business School \\ thanhphamdba@gmail.com \\ Robin Bell \\ University of Worcester \\ r.bell@worc.ac.uk \\ David Newton \\ University of Gloucestershire Business School \\ david@newtonandnewton.co.uk
}

\begin{abstract}
The purposes of this study are to explore in detail the tacit business knowledge transfer process and the effective transfer method from founder to successor in Vietnamese family businesses. This study, using separate interviews of paired founders and successors in five Vietnamese family businesses, aims to contribute to the general understanding of such processes in South East Asian family businesses. This study confirms that the tacit business knowledge transfer process is an on-going process until the founder is unable to continue due to physical or mental health preventing further communication. In addition, it indicates that the mentor-mentee method is the most common method for tacit knowledge transfer process. Storytelling is also a common process; unlike traditional Western SMEs, use of formal documentation tends to be far less prevalent as a way of transferring knowledge. The findings of this study show that not all of tacit business knowledge from the founder is important to the successor. Therefore, a successor needs time spent alone to contemplate each tacit business lesson, before determining whether to absorb it.
\end{abstract}

Keywords: Tacit business knowledge, family business succession, tacit business knowledge learning process, business founders and successors

\section{Introduction}

Previous researchers concluded that family businesses contributed significantly to wealth creation and economic growth in the world (Astrachan \& Shanker, 2003; Basu, 2004; Morck \& Yeung, 2004). However, there are a limited number of family businesses, which survive into the second generation and even less reach the third generation (Handler, 1994; Kellermanns \& Eddleston, 2004). There are many reasons for this, but the failure of succession planning for the next generation is considered as one the main causes (Breton-Miller, Miller, \& Steier, 2004; Cabrera-Suárez, De SaaPerez, \& GarcíaAlmeida, 2001; Mazzola, Marchisio, \& Astrachan, 2008). In addition to the transfer of ownership issues, unfinished sharing tacit business knowledge from predecessor to successor has been demonstrated as one of the primary causes for the lack of sustainability among family firms (Bracci \& Vagnoni, 2011; Cabrera-Suárez et al., 2001; Chirico, 2007). 
Many studies suggest that tacit knowledge can be described as one of the most important strategic resources in any family business (Cabrera-Suárez et al., 2001; Chirico, 2007; Henry, Erwee, \& Kong, 2013; Sobirin \& Sofiana, 2015). CabreraSuárez et al. (2001) argued that understanding the crucial importance of tacit knowledge transfer in a succession process might help to maintain and improve the competitive advantage of a family business. Existing family business literature acknowledge that tacit business knowledge is a key resource to maintain the success across generations; it is often embedded in the owner and other key family members (Brännback, Carsrud, \& Schulte, 2008; Breton-Miller et al., 2004; Cabrera-Suárez et al., 2001; Sobirin \& Sofiana, 2015). To maintain competitive advantage across the generations, tacit business knowledge must be effectively transferred to the next generation (CabreraSuárez et al., 2001; Chirico, 2008a; Henry et al., 2013). Particularly, most Vietnamese family firms are still operating under the control of the first generation and are preparing to transfer tangible and intangible assets to the second generation. Therefore, ensuring founder's tacit business knowledge is effectively transferred to next generation, which is one of the vital issues for Vietnamese family companies, in order to maintain their success through generations. Therefore, the aim of this study is to investigate how tacit business knowledge transfer process is transferred from founder to successor in Vietnamese family business.

\subsection{Definition of Tacit business knowledge}

Nonaka and Takeuchi (1995) differentiate knowledge in an organization into two kinds: explicit knowledge and tacit knowledge. Explicit knowledge is evidenced in documents, figures, and data, so it can be stored and transferred systematically and formally between firm members. However, tacit knowledge is extremely personal and hard to share between members. As Malecki (1997) highlights, the essence of knowledge is depicted as four kinds of knowledge, namely: know-what, know-why, know-how, and know-who. This knowledge is accumulated by the predecessor as tacit business knowledge, which plays a significant role in maintaining competitive advantage. It is a hidden resource which is relatively easy to defend against possible seizure by opponent companies (Cabrera-Suárez et al., 2001; Chirico, 2008b; Haldin-Herrgard, 2011; Sobirin \& Sofiana, 2015)

Chirico (2007, p. 66) indicated that there were three key competences inherent in the predecessor's tacit business knowledge, namely: (1) "Industry-related competences", which are industry unique knowledge; (2) "Business competences", which include the techniques and skills to manage a family business in an effective way. For instance, decision making skills, the skill measure and anticipate future risk, or the way to deal with family business crisis; and finally (3) "Ownership competences", which is related to the predecessor's capacity to be active owner. For example: the skills to handle a reasonable balance between firm's profit and social responsibilities; balancing life and work, etc. As the result, Chirico's (2007) definition was employed as the main definition to this study because it highlights the crucial knowledge that need to be transferred to the successor. 


\section{Literature review}

\subsection{Tacit business knowledge transfer process}

Szulanski (2000) introduced The Process of Knowledge Transfer Model in business organizations and located 4 stages: initiation, implementation, ramp-up and integration. The initiation phase begins as soon as a gap and knowledge to address the gap are found within the firm. The second stage is implementation of knowledge transfer, which follows the decision to transfer knowledge. Ramp-up stage begins once the recipient starts using the knowledge that he/she has accumulated. Lastly, the integration stage starts when satisfactory results are initially obtained and the use of new knowledge becomes gradually routinized.

However, Szulanski 's model (2000) may not be appropriate for a family business. This may be linked to the fact that the process of knowledge transfer happens during the successors' childhood (Haldin-Herrgard, 2011; Sobirin \& Sofiana, 2015). Therefore, it is difficult to identify the precise point when the predecessor decides to transfer (the end point of the initiation stage) or the first day that a successor tries to apply tacit business knowledge (the end point of the implementation stage).

Further research by Varamäki, Pihkala, and Routamaa (2003) has described three stages of transferring knowledge in a case study about family business succession. The first stage is: "Getting to know the field (growing into entrepreneurship)", the second stage is: "Familiarization (actual stage of transferring knowledge)", and the final stage is: "The stage of independent development of the business (creating of new explicit and tacit knowledge)" (Varamäki et al., 2003, p. 12). Importantly, they argue that the key knowledge is transferred after the successor has joined the family business and acknowledge that it is difficult to identify the moment when the knowledge transfer process has been completed.

In the recent research, Sobirin and Sofiana (2015) suggest that there are five stages in knowledge transfer process in family business. First phase is the transfer of philosophical knowledge, the second phase is the transfer of the knowledge of products, the third phase is the transfer of finance management, the forth phase is the transfer of marketing management, and final is the being the leader. However, the problem with all this research is the difficulty of identifying the length of time involved in the whole process of tacit business knowledge transfer.

\subsection{Tacit business knowledge transfer methods in family business}

Nonaka and Takeuchi (1995) proposed a pattern to the transfer of tacit knowledge between individuals, which they say occurs through observation and continuous use and reuse. Bracci and Vagnoni (2011) support this idea by asserting that most knowledge is tacit knowledge and could be transferred and acquired only through observations, application and use. Furthermore, observation and tracking the predecessor's work practices is a key facet of tacit business knowledge transfer process, which leads to, and often triggers the second phase of this process, which is learning-by-doing (Bracci \& Vagnoni, 2011; Cabrera-Suárez et al., 2001). Henry et al. (2013) argued that the knowledge transfer process in a family business is more informal and unstructured, whereas it is more structured and formal in non-family businesses. According to a study by Letonja and Duh (2015), it is really beneficial to let the successor observe the predecessor at work, get involved in daily operations, sit in on meetings and negotiations with partners and to let them find solutions by themselves, thus taking 
responsibility for their decisions. They also found that it is significantly important to let the next generation be involved early and start integrating them into the family business, in order to develop their business competence (Letonja \& Duh, 2015).

In addition, Sabri, Haron, Jamil, and Ibrahim (2014) assert that there are three ways to transfer knowledge in a family business, which are: storytelling, mentor-mentee, and process documents. Storytelling conveys knowledge through verbal language. It is usually informal and unstructured, and it is difficult to forecast the references due to the fact that all of the information is based on individual wisdom. It will involve the explanation of what, why and how something occurred in a particular set of business circumstances (Duh, 2015; Sabri et al., 2014; Simões, Antunes, \& Cranefield, 2016). The Mentor-mentee method means that the predecessor acts as a mentor who has the knowledge, experience and/or expertise and will counsel the successor as a mentee. The successor is the person who will absorb and capture all of the knowledge from the predecessor. Normally, a predecessor will advise what and how to do something, explain why it is done and amend if there is any mistake done by the successor (Rothwell, 2004; Sabri et al., 2014). Lastly, process documents are a method that explains how an issue or business needs to be done or performed through detailed, written instructions (Rothwell, 2004; Sabri et al., 2014).

Overall, although some scholars have done research into how tacit business knowledge is transferred in family businesses, the knowledge they provided is still limited and does not always take into account cultural differences.

\section{Research Method}

\subsection{Research Design}

This research was conducted by using multiple case studies, using semi-structured interviews and designed to look for deeper comprehension of the tacit business knowledge transfer process (TBKTP) from founder to successor in Vietnamese family businesses. As a result, it is crucial to ensure that all of the participants have experiences about TBKTP. Therefore, each case study was selected when they met two requirements. Firstly, a family firm has to be implicated in the TBKTP, and secondly, the succession process should be well advanced, which means that the successor has achieved an important role in the family business.

This study researched the relationship experience between founder and successor in family businesses. However, in Vietnamese culture (collectivism culture) people often want to avoid discussing their family relationship experience with a stranger. Therefore, it is difficult to get the full commitment from participants that is required to ensure a sampling process, which is the best and most reliable for this study. Therefore, there are only seven case studies, which were selected through the researcher's own friendship networks. Access to participants, without the trust between participants and the author, is extremely difficult; therefore, using friendship networks is often the only way to make contact with the participant and gain reliable data for this research. Because of the limitation in personal network, the choice of different gender between participants was not available. Therefore, all participants were male. Although none of the founders have a bachelor degree, all successors, excepted one, had at least a bachelor degree and two of them have a master's degree. In addition, the entire of case studies establish over 15 years and operate in different industries such as construction, agriculture and farming, manufacturing, transportation and trading. 
However, in only one out of the seven cases was the business managed totally by a second-generation successor. The remaining cases were well-advanced in their own succession process, meaning that the successor had achieved a key position in their family firm. Despite the fact that seven cases were chosen for this research, two out of seven cases were incomplete as two owners of the firm did not want to be involved in this study, even though the interview with both of their successors had been completed. Overall, there are five case studies with complete interviews. Both owners and successors in five case family firms were interviewed separately. The names of firms and participants were hidden by coding their name, for example, F1 and S1, F2 and S2, F3 and S3, F4 and S4, and lastly F5 and S5 respectively.

\subsection{Data preparation and data analysis}

All interviews were record in Vietnamese. The transcription was done after interview and sent to a professional translating firm to interpret them into English to avoid personal bias on behalf of the author and minimize the level of distortion.

The English transcript was used for data presentation, while the Vietnamese transcript was used for data analysis process due to avoiding the distortion between two versions. The Thematic Analysis Approach was applied in data analysis process. As the first step, the authors underlined everything from the transcripts, which related to the research questions. Next, they grouped this information into key themes and sub themes. The similarities and differences between the cases were investigated and used to identify the themes and their meanings.

\section{Results and Discussion}

\subsection{Tacit business knowledge transfer process}

Researchers conclude that successors may gain tacit business knowledge before they join the family business (Haldin-Herrgard, 2011) and it is difficult to identify when this process ends (Varamäki et al., 2003). In terms of the first tacit business knowledge successors gain from founders, typical responses were that they were not aware of their first tacit knowledge lesson, because it had been absorbed naturally when they were children and used to play around their father's workplace. For example, S1 revealed that:

"Scolding employees to push them to work is the most memorable lesson I learned as a child. I used to play around the construction site where my father worked. My father explained that business could not be done without pushing employees to work hard."

In addition, all the founders' comments regarding this issue were similar to the successors' responses. They agreed that the process of knowledge transfer happened a long time ago during the successors' childhood. This outcome strongly supports the research of Haldin-Herrgard (2011) who suggests that the process of transferring tacit business knowledge happens over a long period of time, even before the successor joins the family business. In addition, it is consistent with the findings of Varamäki et al.'s study (2003), who indicate that successors are involved in the family business from childhood. Therefore, a part of the founder's tacit business knowledge will be transferred automatically to successor through the family context, for example at meals, 
or during leisure times. As a result, the successor may have access to tacit business knowledge on a daily basis, even if they do not intend to learn it.

Interestingly, there was only one family business, case number four, which was being run completely by the second generation. Both S4 and F4 strongly agreed that the knowledge transfer process only finishes when the founder faces health problems. For example, F4 confirmed that he would continue to transfer his experience into the business and its life, as long as he remained fit, healthy and of sound mind.

"I think as long as we live, we have experience to transfer to the next generation. This means, a 70-year-old man still has something to learn from a 71-year-old man. In addition, my son is still young, so I need to help him to gain as much knowledge as possible".

S4 admitted that he did not know when the process of transferring tacit knowledge would be finished, because he still needed his father's experience in supporting the stable development of the firm. Furthermore, S4 compared the TBKTP and the process of succession in family business, concluding that:

"Overall, the process of transfer of ownership and tangible assets can be finished at the right time, but the process of transfer of tacit knowledge may not ever finish, unless there's an unexpected problem like a health problem."

Although the process of succession had not been completed in the remaining four cases, all successors and founders strongly agreed that the process of tacit knowledge transfer would not finish at the point control passed from founder to successor. This is because tacit knowledge from the founder is critical to the second generation in maintaining the stable development of the firm after the end of the succession process. Interestingly, S3 explained that he believed the end point of this process would only happen when the relationship between father and son ended. S3 elucidated this:

"I suggest that the 'end' means when two people end their relationship and there are no more connections. It won't happen in a family business, because the founder and successor are father and son. The connection between them is a bloodline relationship."

The remaining founders responded with similar idea that the process of transferring ownership and tangible assets should end while the founder was still capable and of sound mind; however, he would still be able to support his successor to run the family business properly. They suggested that the tacit knowledge transfer process only ends when the founder is unable to continue. This is because the founder's experience is valuable, as it has been accumulated from failures. Therefore, successors can avoid the same failures by considering the founder's advice before making any critical decision.

The outcome of this study shows that the TBKTP is an on-going process. It starts in childhood, long before the successor joins the family business. This result is consistent with research by Higginson (2010) and Varamäki et al. (2003), who argue that successors are involved in the family business from early on in their lives. All interviewees agreed that the valuable experience of the founder comprise not only purely business experience, but also includes experience of life, society, and important social network. Furthermore, the role of the founder, after the succession process has been completed, is described as advisory; the founder is always available to support the successor when they need advice to solve business issues or overcome obstacles in their life. In other words, the role of the founder in sustaining the stable development of the 
family business after the succession process is emphasised in this research; it is perceived as a duty by the older generation.

\subsection{Tacit business knowledge transfer methods}

The second aspect of the tacit knowledge transfer process investigated was the methods used within a family business. It is crucial to identify which method is relevant in Vietnamese family businesses. There are three common ways to transfer tacit knowledge, which have been discussed in existing literature, namely: mentor-mentee (Bracci \& Vagnoni, 2011; Cabrera-Suárez et al., 2001; Letonja, Duh, \& Ženko, 2012; Sabri et al., 2014), storytelling (Denning, 2001; Sabri et al., 2014; Swap, Leonard, \& Mimi Shields, 2001), and process documents (Sabri et al., 2014; Ungan, 2006). However, the result from this study contests that there are only two common ways to transfer tacit knowledge in Vietnamese family businesses, which are: the mentormentee approach, and the storytelling. Additionally, participants recommended that the process documents method should be avoided as a way of tacit business knowledge transfer in family businesses, because it is considered as boring and confusing by the successor. With regard to the mentor-mentee method, all founders agreed that the successor has to be involved in all of the daily business issues related to a family business. It means that the successor needs to observe the founder at work, get involved in daily operations, sit in meetings and negotiations with partners, find out solutions by themselves and also take responsibility for decisions. For instance, F1 explained that the main difference between the succession process in a family business and a non-family business is the successor's business competence. In a non-family business, the succession process may happen smoothly, in a short time because there is little difference in the level of business competence between predecessor and successor. However, there is usually a gap in a family business. The successor often lacks business experience, as well as having little business competence. Therefore, the succession process may not happen in a short time, but over a long period. The successor needs to be involved in all the daily business operations, in order to improve business competence. Furthermore, the founder needs to oversee the successor and help them to fix unexpected problems.

F2 revealed that he was playing a mentor role, who instructed his successor (mentee role) about how to run the business properly, why things were done and fixed any mistakes made by his successor. Therefore, the successor may accumulate tacit business knowledge through learning by doing (Bracci \& Vagnoni, 2011; Sabri et al., 2014; Varamäki et al., 2003), and this will help to increase the confidence of the successor. F2 commented that

"At present, I am transferring my business gradually and always backing him up, like singing a duet with him. If he meets difficulties at high tones, I am always ready there to help him. The successor can only grow fast if he does business tasks by himself."

F5 also stressed that the founder should let his successor do business assignments by himself. It is good for the successor to make some mistakes (under the founder's control) and learn from his failures, which could help the successor improve his business competences. From that, the successor may comprehend the tacit business knowledge that the founder wants to transfer to him. F5 discussed that:

"Young people tend to be hasty and think they are capable of doing anything. So, if you try to tell them they are wrong, they may not listen to you. Therefore, the founder should 
let the successor make some mistakes, then they will listen and the tacit knowledge transfer process will become much easier."

In addition, all five successors agreed strongly that mentor-mentee method was the most common way used to transfer tacit business knowledge from founder to successor. For instance, S2 reflected that he has gained a lot of tacit business knowledge through the way the founder trusted him, gave him business tasks and let him take full responsibility for his decisions. However, the founder always offered timely support if the successor was faced with serious business problems and explained why the problem happened.

S3 underlined that gaining tacit business knowledge was a process that takes time. He was new to the family business field, thus he needed to learn step by step during the process of working together with the founder. Key tacit business knowledge was often gained after discussing, with his father, mistakes from real situations, which had failed.

In addition to the key method of mentor-mentee, the storytelling method was used to some extent in family businesses to transfer tacit knowledge through generations. However, there were different perspective between founders and successors. Typical comments from successors were that it is easy to understand tacit business knowledge through story-telling approach but applying this knowledge to specific business situations to resolve problems was difficult. Furthermore, this kind of knowledge was just the founder's judgment and had not been verified. Conversely, a common opinion from founders was that it is a good method to transfer tacit knowledge to successors. For example, F1 recalled that he used to accumulate business experience through stories that were told by other people. Therefore, he also tried to apply this method to his successor by telling him business stories. Overall, they all agree that stories are employed as a method to transfer tacit business knowledge in family business, but successors argue that it is not easy to practise.

Although the mentor-mentee and the story telling methods are common, the process document method was not used in any case study. The main reason given was that tacit knowledge transfer is difficult to understand through papers and the successor may get bored. As S2 argued that:

"People communicate mostly through verbal language. When we can't talk to each other, how can knowledge be transferred? It is boring and difficult to digest knowledge from paper, especially if it is tacit business knowledge."

Overall, this outcome is consistent with previous research (Bracci \& Vagnoni, 2011; Cabrera-Suárez et al., 2001; Letonja et al., 2012). They suggest that tacit business knowledge can be transferred through observations, application and use. The role of the founder is like a mentor who has the tacit business experience and will advise the successor, as a mentee, what and how to do, why it is done and fix any mistakes made by the successor. In addition, the successors prefer to absorb tacit business knowledge from the founder through real business situations, rather than the storytelling method. Importantly, the process document method or the paper writing method should be avoided in the transfer of tacit knowledge.

\subsection{Successor reflection.}

In terms of reflection, Higginson (2010) states that reflection is the ability to allow people to acknowledge new knowledge. In other words, the predecessor and successor 
need to spend quality time together to create a shared understanding, then the successor needs "alone time" to contemplate the new tacit business knowledge that has been gained from the predecessor (Higginson, 2010, p. 10). Although all successors agreed that founder's tacit business knowledge was really important to them, they also believed that not all tacit business knowledge was appropriate to their generation. Therefore, they had to spend alone time to think and refine it before accepting it. For instance, S1 argued that:

"I take only what's [tacit business knowledge from founder] appropriate to myself and reject what's not suitable to my character."

In addition, the TBKTP would be less productive without the reflective step. As S4 said:

"If I do not reflect on what I have discussed with my father, the knowledge I gained from the discussion will soon go into oblivion."

To sum up, the ability to reflect is a significantly important factor in the TBKTP. It is obvious that spending time alone is of paramount importance in supporting the reflective process. The reflective stage, after discussing business issues with the founder, helps the successor to refine, to consider, and select the most appropriate tacit business knowledge from the founder that matches the successor's character. In other words, the process of tacit business knowledge transfer between founder and successor may not be effective without the reflective process.

\section{Conclusion and Implications}

This research contributes to the understanding about the process around the transfer of tacit business knowledge in several ways. First, there is a gap in knowledge about the endpoint of the tacit business knowledge transfer process in family business literature. Researchers argue that it is extremely difficult to identify when the process finishes (Sobirin \& Sofiana, 2015; Varamäki et al., 2003). However, the findings from this research indicate that the tacit business knowledge transfer process is a continuing process until the founder is physically unable to continue.

Secondly, the tacit business knowledge of the founder plays an important role in supporting the succession process in Vietnamese family businesses. However, the findings of this study indicate that not all of this knowledge is important to the successor. Therefore, successors should spend more time alone to consider each of the founder's tacit business knowledge lessons, in order to decide which lesson is relevant or irrelevant to the way they work or their general characteristics. This process may help the successor gain tacit business knowledge from the founder more productively.

Thirdly, this research suggests that practitioners should employ a mentor-mentee relationship as the best method of supporting the tacit business knowledge transfer process. Storytelling is also common method to transfer tacit knowledge in Vietnamese family businesses. However, the founders should avoid using process documents as a way of transferring knowledge.

In common with any research, this research has its limitations and it is important to address them. Firstly, the gender issue is one of the research limitations. All participants were male, therefore, this research result may not be relevant to family companies, where founder and successor's gender are different. As a consequence, future research may expand this research by choosing different case studies with different genders. The 
second limitation is sample size. Although the sample is small, it provides a foundation of knowledge for future studies about the TBKTP in Vietnamese family companies. Further research needs to extend this research by employing quantitative or mixed methods to deal with this limitation.

The third limitation is that the outcomes are heavily dependent on the experience of two key actors in the TBKTP (the founder and the successor). Therefore, it may not be representing all aspects of this process in family firms. Future studies may overcome this limitation by considering other family members' perspective, instead of only concentrating on the perspective of the founder and the successor. The fourth limitation is that this study is only interested in the knowledge flow from founder to successor. Therefore, future studies may consider the knowledge transfer process from successor to founder or between other important family members, rather than only focussing on the TBKTP from the founder to the successor. 


\section{References}

Astrachan, J. H., \& Shanker, M. C. (2003). Family Businesses' Contribution to the US Economy: A Closer Look. Family Business Review, 16(3), 211-219.

Basu, A. (2004). Entrepreneurial Aspirations Among Family Business Owners: An Analysis of Ethnic Business Owners in the UK. International Journal of Entrepreneurial Behavior \& Research, 10(1/2), 12-33.

Bracci, E., \& Vagnoni, E. (2011). Understanding Small Family Business Succession in a Knowledge Management Perspective. IUP Journal of Knowledge Management, 9(1), 7-36.

Brännback, M., Carsrud, A., \& Schulte, W. D. (2008). Exploring the Role of Ba in Family Business Context. Vine, 38(1), 104-117.

Breton-Miller, I. L., Miller, D., \& Steier, L. P. (2004). Toward an Integrative Model of Effective FOB Succession. Entrepreneurship theory and practice, 28(4), 305328.

Cabrera-Suárez, K., De Saa-Perez, P., \& García-Almeida, D. (2001). The Succession Process from A Resource-And Knowledge-Based View of The Family Firm. Family Business Review, 14(1), 37-46.

Chirico, F. (2007). The Accumulation Process of Knowledge in Family Firms. Electronic Journal of Family Business Studies, 1(1), 62-90.

Chirico, F. (2008a). The Creation, Sharing and Transfer of Knowledge in Family Business. Journal of Small Business \& Entrepreneurship, 21(4), 413-433.

Chirico, F. (2008b). Knowledge Accumulation in Family Firms Evidence from Four Case Studies. International Small Business Journal, 26(4), 433-462.

Denning, S. (2001). The springboard: How storytelling ignites action in knowledge-era organizations: Routledge.

Duh, M. (2015). Succession Process: A Chance for Rebirth or Failure of a Family Business. International Journal of Business and Management, 10(3), 45.

Haldin-Herrgard, P. T. (2011). Tacit Knowledge Diffusion in Family Business Succession. Swedish school of Economics and Business Administration in Vaasa. Downloaded, 3.

Handler, W., C. (1994). Succession in Family Business: A Review of the Research. Family Business Review, 7(2), 133-157.

Henry, M., Erwee, R., \& Kong, E. (2013). Insights from Canadian case studies on succession and knowledge transfer in family firms. Paper presented at the Third Annual International Conference on Engaged Management Scholarship, Atlanta, Georgia.

Higginson, N. (2010). Preparing the Next Generation for the Family Business: Relational Factors and Knowledge Transfer in Mother-To-Daughter Succession. Journal of Management \& Marketing Research, 4(1), 1-18.

Kellermanns, F. W., \& Eddleston, K. A. (2004). Feuding Families: When Conflict Does a Family Firm Good. Entrepreneurship theory and practice, 28(3), 209-228.

Letonja, M., \& Duh, M. (2015). Successors' Innovativeness as a Crucial Succession Challenge of Family Businesses in Transition Economies: The Case of Slovenia Family Businesses in Transition Economies (pp. 157-174): Springer.

Letonja, M., Duh, M., \& Ženko, Z. (2012). Importance of Transferring Tacit and Experiential Knowledge as well as Social Capital of Founders for Innovativeness of Successors in Smaller Family Firms. Paper presented at the 10th International Conference on Management, Enterprise and Benchmarking (MEB 2012). 
Malecki, E. J. (1997). Technology and Economic Development: The Dynamics of Local, Regional, and National Change (2nd Ed.). London: Addison Wesley Longman.

Mazzola, P., Marchisio, G., \& Astrachan, J. (2008). Strategic Planning in Family Business: A Powerful Developmental Tool for The Next Generation. Family Business Review, 21(3), 239-258.

Morck, R., \& Yeung, B. (2004). Family control and the rent-seeking society. Entrepreneurship theory and practice, 28(4), 391-409.

Nonaka, I., \& Takeuchi, H. (1995). The Knowledge-Creating Company: How Japanese Companies Create the Dynamics of Innovation: Oxford University Press.

Rothwell, W. (2004). Knowledge Transfer: 12 Strategies for Succession Management. IPM-HR NEWS.

Sabri, S. M., Haron, H., Jamil, N., \& Ibrahim, E. N. M. (2014). Intergenerational Knowledge Transfer Strategy Framework for Family Firm. Paper presented at the Regional Conference on Science, Technology \& Social Sciences at Copthorne Hotel Cameron Highlands, Pahang, Malaysia.

Simões, D., Antunes, P., \& Cranefield, J. (2016). Enriching Knowledge in Business Process Modelling: A Storytelling Approach. Innovations in Knowledge Management (pp. 241-267): Springer.

Sobirin, A., \& Sofiana, A. (2015). Tacit and Idiosyncratic Knowledge Transfer in The Family Firm. International Journal of Family Business, 13(9), 6913-6936.

Swap, W., Leonard, D., \& Mimi Shields, L. A. (2001). Using Mentoring and Storytelling to Transfer Knowledge in The Workplace. Journal of Management Information Systems, 18(1), 95-114.

Szulanski, G. (2000). The Process of Knowledge Transfer: A Diachronic Analysis of Stickiness. Organizational Behaviour and Human Decision Processes, 82(1), 927.

Ungan, M. (2006). Towards A Better Understanding of Process Documentation. The TQM Magazine, 18(4), 400-409.

Varamäki, E., Pihkala, T., \& Routamaa, V. (2003). Stages of Transferring Knowledge in Small Family Business Successions. Paper presented at the Proceedings of Family Business Network 14th Annual World Conference. 


\section{Appendix - Case profiles}

\begin{tabular}{|c|c|c|c|c|c|}
\hline & Firm 1 & Firm 2 & Firm 3 & Firm 4 & Firm 5 \\
\hline \multicolumn{6}{|c|}{ Firm Info } \\
\hline Industry & Construction & Manufacturing & Agriculture & Transportation & Farming \\
\hline $\begin{array}{l}\text { Date firm } \\
\text { established }\end{array}$ & $\begin{array}{c}\text { The late } \\
1990 \mathrm{~s}\end{array}$ & $\begin{array}{c}\text { The early } \\
2000 \mathrm{~s}\end{array}$ & $\begin{array}{c}\text { The early } \\
1990 \mathrm{~s}\end{array}$ & $\begin{array}{c}\text { The early } \\
1990\end{array}$ & $\begin{array}{c}\text { The early } \\
2000 \mathrm{~s}\end{array}$ \\
\hline Location & $\begin{array}{l}\text { North of } \\
\text { Vietnam }\end{array}$ & $\begin{array}{l}\text { North of } \\
\text { Vietnam }\end{array}$ & $\begin{array}{l}\text { North of } \\
\text { Vietnam }\end{array}$ & $\begin{array}{l}\text { South of } \\
\text { Vietnam }\end{array}$ & $\begin{array}{l}\text { South of } \\
\text { Vietnam }\end{array}$ \\
\hline \multicolumn{6}{|c|}{ Founder Demographics } \\
\hline Gender & Male & Male & Male & Male & Male \\
\hline Age & $\begin{array}{c}\text { The early } \\
50 \mathrm{~s}\end{array}$ & The early $50 \mathrm{~s}$ & $\begin{array}{c}\text { The early } \\
60 \mathrm{~s}\end{array}$ & The early $50 \mathrm{~s}$ & $\begin{array}{c}\text { The early } \\
50 \mathrm{~s}\end{array}$ \\
\hline Education & High school & High school & High school & High school & High school \\
\hline \multicolumn{6}{|c|}{ Successor Demographics } \\
\hline Gender & Male & Male & Male & Male & Male \\
\hline Age & The late $20 \mathrm{~s}$ & The early $30 \mathrm{~s}$ & $\begin{array}{c}\text { The middle } \\
30 \mathrm{~s}\end{array}$ & $\begin{array}{c}\text { The middle } \\
30 \mathrm{~s}\end{array}$ & $\begin{array}{c}\text { The late } \\
20 \mathrm{~s}\end{array}$ \\
\hline Education & MBA & $\begin{array}{l}2 \text { Master's } \\
\text { degrees }\end{array}$ & $\begin{array}{c}\text { Bachelor } \\
\text { degree }\end{array}$ & High school & $\begin{array}{c}2 \text { Bachelor } \\
\text { degrees }\end{array}$ \\
\hline $\begin{array}{l}\text { External } \\
\text { working } \\
\text { experience }\end{array}$ & $\begin{array}{l}\text { Part-time } \\
\text { jobs }\end{array}$ & None & Yes & None & Yes \\
\hline
\end{tabular}

